\title{
HYVINVOINTIA PAIKALLISTAMASSA - MAASEUDUN PAIKALLISTEN HYVINVOINTIJÄRJESTELMIEN TEOREETTINEN TULKINTAMALLI
}

\author{
Mari Kattilakoski: YTL, projektitutkija, väitöskirjatutkija, Itä-Suomen yliopisto \\ Niina Rantamäki: YTM, projektitutkija, väitöskirjatutkija, Jyväskylän yliopisto, \\ Kokkoolan yliopistokeskus Chydenius
}

mari.kattilakoski@uef.fi;niina.rantamaki@.chydenius.fi

Janus vol. 28 (4) 2020, 374-391

\section{Tiivistelmä}

Jäsennämme artikkelissa maaseudun paikallisyhteisöjen hyvinvoinnin muotoutumiseen liittyviä tekijöitä. Lähtökohtanamme toimii paikallisten hyvinvointijärjestelmien teoria, jonka pohjalta kehitämme maaseudun paikallisyhteisöjen hyvinvoinnin analyysiin soveltuvaa teoreettista tulkintamallia. Tässä käytämme apuna sosiaalitieteestä käsin rakentuvaa kompleksisuusajattelua. Nostamme esiin neljä alkuperäistä teoriaa täydentävää ja laajentavaa ulottuvuutta: paikallisuuden määrittymiseen vaikuttavat tekijät, kokonaisvaltainen näkökulma hyvinvointiin, vuorovaikutusta ja osallisuutta edistävät rakenteet ja toimintakäytännöt sekä tulevaisuusperspektiivi. Tältä pohjalta esittelemme maaseudun paikallisten hyvinvointijärjestelmien teoreettisen tulkintamallin, jonka avulla on mahdollista tunnistaa ja ymmärtää niitä moninaisia tekijöitä, joilla on vaikutusta ja merkitystä maaseutuyhteisöjen paikallisen hyvinvoinnin muotoutumisessa.

\section{JOHDANTO}

Vuoden 2009 alussa satavuotinen Ullavan kunta liitettiin osaksi Kokkolan kaupunkia. Sen myötä vajaan 800 ullavalaisen asioista alettiin päättää Kokkolan kaupungintalolla, jonne entiskunnan keskustasta on matkaa 50 kilometrïa. Vaikka muutosta ei alkuvaiheessa arjessa juuri huomannut, olivat asukkaat varuillaan. Kokemukset eri puolilta Suomea olivat osoittaneet, että kuntaliitosten myötä entisten maalaiskuntien palvelut tulevat väistämättä heikkenemään. Ullavassa ensimmäinen hälytysmerkki uhkakuvien toteutumisesta oli kirkonkylän kaupan sulkeutuminen. Kyläläisille kauppa edusti eräänlaista "puskuria" sille, etteivät muutkin palvelut karkaa kaupungin keskustaan. Muuttaakseen näköpiirissä siintävää kehityssuuntaa asukkaat perustivat palveluosuuskunnan, jonka ensimmäinen tehtävä oli palauttaa kauppapalvelut kylälle. Kyläkaupan uudelleen avaamisen jälkeen osuuskunta on laajentanut toimintaansa myös muihin asukkaiden toivomiin palveluihin. Lisäksi yhteistyössä muiden paikallisten toimijoiden kanssa se järjestää erilaisia kyläläisiä yhteen kokoavia tapahtumia ja toimintoja. Pyrkimyksenä on vahvistaa sekä kauppatoiminnan taloudellista pohjaa että toiminnan yhteisöllistä oikeutusta. Tärkein on kuitenkin jo saavutettu: peruspalvelut ovat säilyneet, ja sitä myötä Ullava näyttäytyy edelleen houkuttelevana asuinpaikkavaihtoehtona myös nuorille perheille.

Edellä kuvattu Ullavan tapaus on yksi esimerkki siitä, millaisia konkreettisia seurauksia jo 1990-luvulla käynnistyneet pyrkimykset hyvinvointivaltion 
uudistamiseksi (ks. Julkunen 2017) ovat paikallistasolla saaneet. Näiden joukossa on maalaiskuntien ja -kylien hiljaisesta hiipumisesta kertovia tarinoita, mutta myös Ullavan kaltaisia esimerkkejä siitä, kuinka maaseutuyhteisöt ovat muuttuneessa yhteiskunnallisessa tilanteessa erilaisten innovatiivisten ja yhteisöllisten ratkaisujen kautta onnistuneet turvaamaan lähipalveluja ja jopa kehittämään niitä (Leinamo 2010; Matthies ym. 2011a; Kumpulainen 2012a; Valkama 2013; Kattilakoski 2015). Monenlaisia vaiheita läpikäyneissä pyrkimyksissä uudistaa julkisten palvelujen rakenteita ja hallintoa on paikallinen ja yhteisöllinen näkökulma jäänyt kuitenkin marginaaliin (Kröger 2017; Pohjola 2017). Näin huolimatta siitä, että tutkijat niin kansallisesti kuin kansainvälisesti (esim. Möttönen \& Niemelä 2005; Hvinden \& Johansson 2007; MacKinnon \& Derickson 2012; Pestoff ym. 2015) ovat korostaneet vaikuttavan ja kustannustehokkaan palvelujärjestelmän edellyttävän julkisen sektorin ja kansalaisyhteiskunnan uudenlaista kumppanuutta. Alberta Andreottin ja Enzo Mingionen (2016) mukaan taustalla voidaan tunnistaa kaksi keskeistä tekijää. Ensinnäkin kyse on tarpeesta löytää tehokkaampia keinoja vastata yksilöllistyviin ja paikallisesti eriytyviin hyvinvointitarpeisiin sekä siinä ohessa laajentaa aktiivista sosiaalipolitiikkaa. Toinen syy liittyy pyrkimyksiin tasapainottaa julkista taloutta. Etenkin kolmannen sektorin tutkijoiden suunnalta (esim. Beresford 2010; Evers 2009; Evers \& Guillemard 2012; Matthies 2014) on korostettu lisäksi demokratianäkökulmaa: julkisissa palveluissa ei ole kyse pelkästään "palveluksista" vaan myös kohtaamisista, jotka sekä luovat että muokkaavat käsityksiä yhteiskunnan ja kansalaisten välisestä suhteesta.

Tässä artikkelissa kiinnostuksemme kohteena on suomalaisen maaseudun, erityisesti harvaan asutun ja ydinmaaseudun (ks. Helminen ym. 2014), paikallisyhteisöjen hyvinvointi. Paikallisyhteisöillä viittaamme tässä moniulotteisista vuorovaikutusverkostoista rakentuviin sosiaalisiin järjestelmiin, joita määrittää myös alueellinen ulottuvuus (vrt. Byrne 2001; Rannikko 2009). Harvaan asutun ja ydinmaaseudun paikallisyhteisöjen arjen maantiedettä raamittavat muuta maata nopeammin ikääntyvä ja vähenevä väestö, korkea huoltosuhde sekä supistuva ja etääntyvä palveluverkko, mikä aiheuttaa hyvinvointipolitiikan toteuttamiselle erityisiä haasteita. Useat tutkimukset osoittavat palvelujen saavutettavuuteen liittyvien ongelmien olevan jo monin paikoin maaseudun arkitodellisuutta (Tedre \& Pulkkinen 2010; Hämeenaho 2012; Kivelä 2014; Bock 2016; Tedre ym. 2016). Niin ikään hyvinvoinnin alueellista jakautumista tarkastelevissa tutkimuksissa (Kauppinen \& Karvonen 2014; Karvonen 2015; Saarsalmi ym. 2017) maaseudun syrjäiset alueet asettuvat toiseksi ääripääksi suhteessa hyvinvoiviin sisempiin kaupunkialueisiin, kaupunkien läheiseen maaseutuun ja ruotsinkieliseen rannikkoseutuun. Toisaalta esimerkiksi Saarisen ja kumppaneiden (2013) tutkimuksen mukaan maaseudun haja-asutusalueiden asukkaat kokevat itsensä kaikkein onnellisimmiksi.

Edellä kuvatut kehityskulut ja osin ristiriitaiset tutkimustulokset ovat osoitus niistä haasteista, joita hyvinvoinnin ymmärtämiseen liittyy. Hyvä- tai huono- 
osaisuutta kuvaavat mittarit sekä näiden pohjalta tehtävät yleistykset ja tilastolliset keskiarvot eivät näytä yksinään tavoittavan hyvinvoinnin moninaisuutta eivätkä selittävän sen paikallisesti eriytyvää kehitystä. Tulokset kertovat myös siitä, että hyvinvointiin liittyvät kysymykset ovat terveyttä, toimeentuloa ja institutionaalisia tekijöitä - kuten palveluja - monisyisempiä.

Tässä artikkelissa tavoitteenamme on jäsentää laaja-alaisesti maaseudun paikallisyhteisöjen hyvinvoinnin muotoutumiseen vaikuttavia tekijöitä. Lähtökohtanamme toimii paikallisten hyvinvointijärjestelmien teoria, jonka pohjalta kehitämme maaseudun paikallisyhteisöjen hyvinvoinnin analyysiin soveltuvaa teoreettista tulkintamallia. Tässä käytämme apuna todellisuuden ja sosiaalisten rakenteiden moniulotteista luonnetta korostavaa kompleksisuusajattelua. Artikkelimme on luonteeltaan teoreettinen, mutta kuten yhteiskuntatieteissä yleensäkin, se ei ole syntynyt tyhjiössä tai ympäröivästä maailmasta irrallaan. Erityisen reflektiopohjan sille muodostavat vuosien 2008-2019 aikana toteuttamamme maaseudun hyvinvointia sekä hyvinvointipalveluja kansalaisosallistumisen ja paikallisyhteisöjen näkökulmista tarkastelleet tutkimuksemme (Matthies ym. 2011a ja 2011b; Kattilakoski ym. 2011; Matthies \& Rantamäki 2013; Kattilakoski 2015; Kattilakoski \& Rantamäki 2016; Rantamäki 2017; Rantamäki \& Kattilakoski 2017 ja 2019).

Kuvaamme aluksi paikallisten hyvinvointijärjestelmien teorian keskeiset piirteet, minkä jälkeen tarkastelemme sen soveltuvuutta maaseutukontekstiin sosiaalitieteestä käsin rakentuvaa kompleksisuusajattelua hyödyntäen. Seuraavaksi paneudumme tarkemmin tunnistamiimme neljään alkuperäistä teoriaa täydentävään ja laajentavaan ulottuvuuteen: paikallisuuden määrittyminen paikallisten hyvinvointijärjestelmien kontekstissa, kokonaisvaltainen näkökulma hyvinvointiin, vuorovaikutusta ja osallisuutta edistävät rakenteet ja toimintakäytännöt sekä tulevaisuusperspektiivin kautta avautuvat näköalat. Etenemme kokoamalla tulokset yhteen sekä esittelemällä maaseudun hyvinvoinnin paikalliseen rakentumiseen vaikuttavien tekijöiden teoreettisen tulkintamallin. Artikkelin lopuksi pohdimme mallin hyödynnettävyyttä maaseudun paikallisyhteisöjen hyvinvoinnin ymmärtämisessä sekä sen tarjoamia laajempia näköaloja hyvinvoinnin tutkimukseen.

\section{Paikallisten \\ HYVINVOINTJJ̈̈RJESTELMIEN TEORIA}

Italialaisten sosiologien Enzo Mingionen ja Marco Obertin (2003) alun perin esittelemä paikallisten hyvinvointijärjestelmien teoria (Local Welfare Systems, LWS) on tarkoitettu analyyttiseksi työkaluksi, jonka avulla voidaan ymmärtää sekä kuvata hyvinvoinnin ja hyvinvointipolitiikan alueellista ulottuvuutta. Mingione sekä kehittämistyötä hänen kanssaan jatkaneet Alberta Andreotti ja Emanuele Polizzi (2012, 1926) viittaavat paikallisten hyvinvointijärjestelmien käsitteellä rajatulla maantieteellisellä alueella toimivaan $d y$ naamiseen järjestelmään, jossa paikalliset sosioekonomiset ja kulttuuriset olosuhteet vaikuttavat siihen, millaisia hyvinvointitarpeita sekä toisaalta eri sektoreita edustavien 
toimijoiden yhdistelmiä ja näiden tuottamia hyvinvointiresursseja tarkasteltavalla alueella syntyy. Paikallisten hyvinvointijärjestelmien teoria suuntaa katseen kansallisen hyvinvointipolitiikan konkretisoitumiseen paikallistasolla sekä tekee näkyväksi kansallisen ja paikallisen hyvinvointipolitiikan leikkauspisteessä vaikuttavia moninaisia tekijöitä. Teorian kehittäminen on tapahtunut lähinnä keski- ja eteläeurooppalaisissa kaupungeissa toteutettujen vertailevien tapaustutkimusten kautta. Näissä kiinnostus on kohdistunut työllisyyspolitiikan paikallistason vaikutuksiin. (Andreotti \& Mingione 2013 ja 2016.) Hyvinvointiteorioiden nelikentässä (ks. Saari 2011, 34-38) paikallisten hyvinvointijärjestelmien teoria sijoittuu resurssipohjaista hyvinvointikäsitystä edustavaan tutkimustraditioon, jonka keskiössä ovat objektiivisesti mitattavissa olevat resurssit ja niiden luomat mahdollisuudet tarpeiden tyydytykseen sekä hyvinvointierojen vertailtavuus. Lisäksi paikallisten hyvinvointijärjestelmien teoriassa voidaan tunnistaa yhtymäkohtia hyvinvointivaltion reformia ja tätä käsitteleviä paradigmoja koskeviin keskusteluihin (esim. Moisio 2012) mukaan lukien valtion ja kansalaisyhteiskunnan välisen suhteen tarkastelu.

Andreotti ja Mingione (2013 ja 2016) katsovat kansallisen hyvinvointimallin ja sen alueellisen toimeenpanon muodostavan perustan sille, miten yhteiskunnan hyvinvointivastuu määrittyy ja kuinka hyvinvointiresurssit jakautuvat. Jokaisella alueella ja paikalla on oma historiansa, taloudelliset ja demografiset erityispiirteensä sekä poliittinen ja sosiaalinen kulttuuri, joihin kansallinen hyvinvointimalli ja sen alueellinen toimeenpano sulautuvat. Sosiaalidemo- kraattiselle hyvinvointimallille perustuva suomalainen hyvinvointivaltio (ks. Esping-Andersen 1990) eroaa jo lähtökohdiltaan kontekstista, jossa paikallisten hyvinvointijärjestelmien teoriaa on alun perin kehitelty. Siinä missä suomalaista hyvinvointimallia luonnehtii laaja ja kattava julkinen palvelujärjestelmä, korostaa mannereurooppalainen konservatiivinen malli perheyhteisöjen roolia (Heinonen 2019, 14).

Paikallisten hyvinvointijärjestelmien teorian pyrkimyksenä on auttaa ymmärtämään hyvinvointitarpeiden ja näihin vastaavien resurssien paikallista muotoutumista sekä toisaalta etsiä ratkaisuja siihen, kuinka yhä eriytyvimpiin tarpeisiin voidaan vastata kohdennetummin. Lähtökohtana hyvinvointitarpeiden tunnistamisessa (Kuvio 1) on väestö- ja työpaikkarakennetta sekä sosio-spatiaalisia olosuhteita kuvaavien tekijöiden analyysi, jossa keskiöön asettuu haavoittuvassa asemassa olevien väestöryhmien identifiointi. Hyvinvointia tukevien resurssien osalta katse suuntautuu eri toimijasektoreiden palvelutarjontaan ja näiden keskinäiseen yhteistyöhön. Sillä, mitä taustasektoria eri toimijat edustavat, ei sinällään ole erityistä merkitystä. Olennaista on ymmärtää, kuinka ja millaisten resurssien kautta hyvinvointia paikallistasolla tuotetaan, miten hyvinvointivastuu institutionalisoituu sekä mikä on toiminnan yhteisöllinen legitimiteetti. Julkisen sektorin osalta huomio suuntautuu lisäksi siihen, millaiset ovat sen valmiudet edistää eri toimijoiden keskinäistä yhteistyötä ja kansalaisten osallistumismahdollisuuksia, sekä millaista vastuunottoa paikallistason toimijoilta ylipäätään edellytetään. (Andreotti \& Mingione 2016.) 

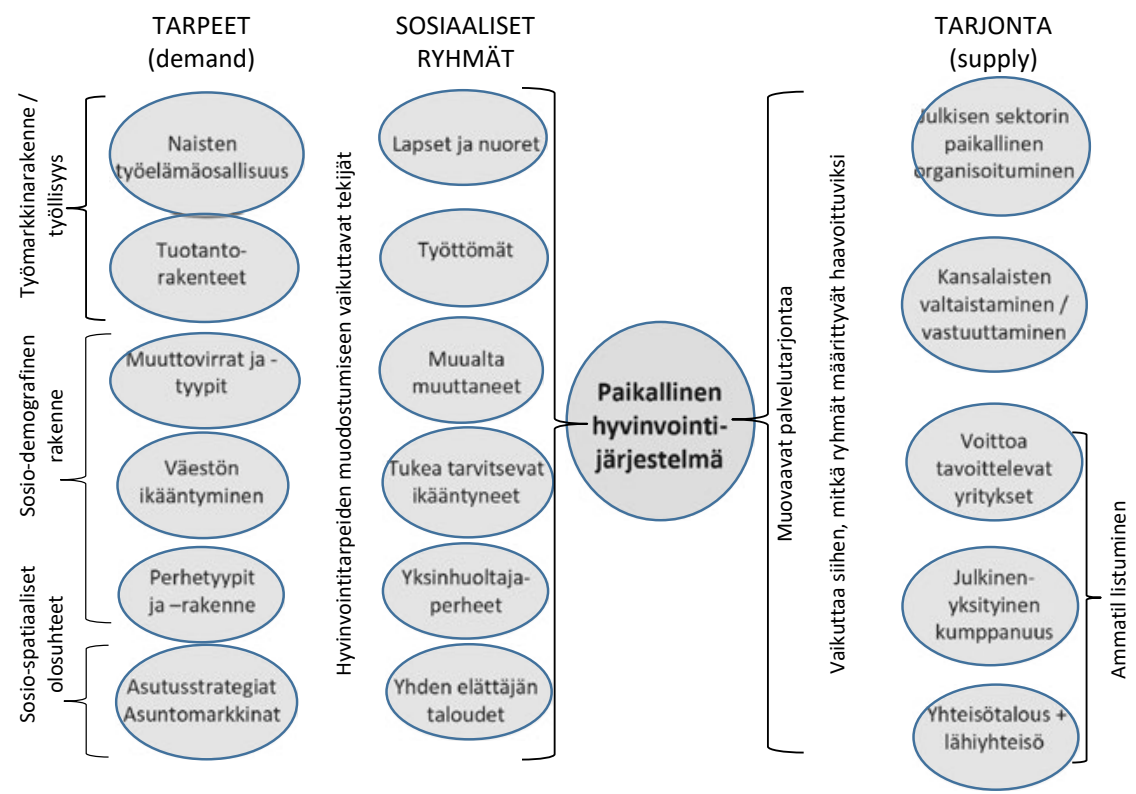

Kuvio 1. Paikallisten hyvinvointijärjestelmien analyysiä ohjaavat hyvinvointitarpeiden ja -resurssien ulottuvuudet (Andreotti \& Mingione 2016)

KOHTI MAASEUDUN PAIKALLISYHTEISÖJEN HYVINVOINNIN YMMÄRTÄMISTÄ

- KOMPLEKSISUUSAJATTELUN AVAAMAT NÄKÖALAT

Systeemiteorian uuteen paradigmaan sitoutuva kompleksisuusajattelu (complexity thinking) tarjoaa holistisen ja monitieteisen lähestymistavan maaseudun paikallisten hyvinvointijärjestelmien rakenteen ja toiminnan jäsentämiseen. Irtautuen lineaarisesta maailmankuvasta se pyrkii ymmärtämään asioiden monimutkaisia riippuvuussuhteita nähden ne luonnollisena ja olennaisena osana sosioekonomisten systeemien toimintaa (Jalonen 2006). Yleisiä lainalaisuuksia etsivän nomoteettisen tiedonintressin sijaan kompleksisuusajattelu kohdistaa kiinnostuksen sosiaalisten systeemien sisäiseen ja keskinäiseen dynamiikkaan sekä niiden sisältäpäin tapahtuvaan muutokseen. Erityisenä pyrkimyksenä on tunnistaa asioiden moninaiset (non-simple) sekä paikoin piilossa olevat kytkökset ja sidokset: tarkastella ja ymmärtää systeemin toimintaa liittyviä tekijöitä erilaisia selitysmalleja hyödyntäen. (Byrne 1998; Cilliers 1998; Ståhle 2004; Vartiainen \& Raisio 2011.)

Kompleksisuusajattelussa korostuu ymmärrys siitä, että nykyisyyden ohella sosiaalisten systeemien toiminnassa on aina läsnä niin menneisyys kuin tulevaisuuden ennakoimattomuus. Sosiaaliset systeemit kehittyvät ja toimivat osana ympäristöään, aikaisempiin tapahtumiin ja institutionaalisiin rakenteisiin kytkeytyen. Suhteessa tulevaisuuteen systeemit ovat osin oman historiansa ja 
kehityskaarensa "vankeja": siihen, millaisena tulevaisuus näyttäytyy, vaikuttaa menneisyys, jonka myötä toiset näköalat ovat enemmän mahdollisia kuin toiset. Sosiaalisten systeemien tulevaisuus ei kuitenkaan ole "annettu" ja ennakoitavissa vaan avoin. Mahdollisuus tunnistaa vaihtoehtoisia kehityspolkuja sekä ylipäätään niiden synty perustuvat ennen kaikkea systeemin ja sen eri osien sekä systeemin ja toimintaympäristön väliseen vuorovaikutukseen. (Byrne 2005; Puustinen \& Jalonen 2020.)

Paikallisten hyvinvointijärjestelmien teorian taustalla voidaan selkeästi tunnistaa kompleksisuusajattelun vaikutus. Andreotti ja kumppanit (2012; myös Andreotti \& Mingione 2013) kuvaavat hyvinvointijärjestelmiä dynaamisina systeemeinä, jotka rakentuvat paikallisten olosuhteiden ja toimijaverkostojen kokonaisuudesta sekä suhteessa ympäröivään kansalliseen ja ylikansalliseen säätelyjärjestelmään. He eivät näe paikallisten hyvinvointijärjestelmien kehitystä lineaarisena tai yksinkertaisiin kausaliteetteihin palautuvana, vaan luonnehtivat sitä moniulotteiseksi, ennakoimattomaksi sekä lukuisten yhteiskunnallisten prosessien yhtäaikaisessa läsnäolossa muotoutuvaksi (vrt. Byrne 2005). Kuten Taulukosta 1 voi havaita, nostaa maaseutunäkökulma kuitenkin esiin joukon kysymyksiä, joiden tarkasteluun alkuperäinen paikallisten hyvinvointijärjestelmien teoria ei tarjoa riittäviä työkaluja.

Edellä esitetyn pohjalta tunnistamme neljä paikallisten hyvinvointijärjestel- mien toimintaan kiinteästi liittyvää ulottuvuutta, joihin maaseutunäkökulma ohjaa paneutumaan tarkemmin. Artikkelin johdannossa sivusimme lyhyesti sitä, kuinka maaseutu on viimeisten vuosikymmenten aikana ollut suurten muutosten kohteena. Vuonna 2006 käynnistyneen kunta- ja palvelurakenneuudistuksen seurauksena maaseutukuntien määrä on vähentynyt merkittävästi. Toteutuneiden kuntaliitosten myötä hallinnolliset rajat vastaavat yhä heikommin ihmisten kokemusta paikallisyhteisyydestä (Kumpulainen 2014). Maaseudun paikallisyhteisöjen hyvinvoinnin tarkastelu edellyttääkin alkuun tarkempaa pohdintaa siitä, mitä paikallinen tässä viitekehyksessä tarkoittaa. Toiseksi, vaikka paikallisten hyvinvointijärjestelmien teoria korostaa laaja-alaista lähestymistapaa, ei se pitkälti tilastolliseen ja tiettyihin politiikkasektoreihin keskittyvään tarkasteluun nojautuessaan kykene riittävästi tavoittamaan hyvinvoinnin monimuotoista ja -ulotteista luonnetta. Kolmanneksi, vaikka alkuperäinen teoria painottaa hyvinvointiresurssien analyysissä eri toimijoiden keskinäisen yhteistyön ja kansalaisyhteiskunnan tarkastelua, ei se tarjoa tarkempia suuntaviivoja siihen, mitä kautta vuorovaikutusta ja yhteistyön rakentumista voidaan lähestyä. Neljäs, tarkempaa pohdintaa vaativa kysymys liittyy "mahdollisuuksien tila" -ulottuvuuden kautta esiin nousevaan tarpeeseen tunnistaa maaseudun paikallisyhteisöjen tulevaisuuden kannalta merkityksellisiä kehityskulkuja, samoin kuin paikallisyhteisöjen edellytyksiä vastata näihin. 
Taulukko 1. Paikalliset hyvinvointijärjestelmät kompleksisina systeemeinä sekä maaseutunäkökulman esiin nostamat kysymykset (pohjautuen Vartiainen \& Raisio 2011; Andreotti \& Mingione 2013 ja 2016)

\begin{tabular}{|c|c|c|}
\hline Kompleksisen systeemin ominaisuudet & $\begin{array}{l}\text { Paikalliset hyvinvointijärjestelmät } \\
\text { kompleksisina systeemeinä }\end{array}$ & $\begin{array}{l}\text { Maaseudun paikallisyhteisöjen hyvinvoinnin } \\
\text { näkökulmasta esiin nousevat kysymykset }\end{array}$ \\
\hline $\begin{array}{l}\text { KESKINÄINEN RIIPPUVUUS: } \\
\text { Systeemin toimijoiden ja sen } \\
\text { ympäristön välinen riippuvuussuhde on } \\
\text { toiminnan ydin. Jokainen toimija saa } \\
\text { aikaan vaikutuksia systeemissä. }\end{array}$ & $\begin{array}{l}\text { Paikallisessa toimintaympäristössä } \\
\text { muotonsa saava kokonaisuus, jonka } \\
\text { puitteissa hyvinvointitarpeet ja - } \\
\text { resurssit sekä kansallisen } \\
\text { hyvinvointipolitiikan alueellinen } \\
\text { toimeenpano konkretisoituvat. }\end{array}$ & $\begin{array}{l}\text { Kuinka kansallinen hyvinvointipolitiikka vaikuttaa } \\
\text { maaseudun paikallisyhteisöjen kehitykseen ja } \\
\text { toisinpäin? } \\
\text { Millainen on toimintaympäristön ja hyvinvoinnin } \\
\text { välinen yhteys sekä miten ne vaikuttavat toisiinsa? }\end{array}$ \\
\hline $\begin{array}{l}\text { YHTEISEVOLUTIONAARISUUS: } \\
\text { Systeemi on aina osa laajempaa } \\
\text { ekosysteemiä. }\end{array}$ & $\begin{array}{l}\text { Paikalliset hyvinvointijärjestelmät } \\
\text { (yleisimmin kunta) toimivat vallitsevan } \\
\text { hyvinvointipolitiikan ja } \\
\text { yhteiskuntarakenteen kehyksessä. } \\
\text { Globaalit ja yhteiskunnalliset } \\
\text { kehityskulut vaikuttavat hyvinvointi- } \\
\text { politiikan muotoutumiseen ja edelleen } \\
\text { hyvinvointijärjestelmien toimintaan. }\end{array}$ & $\begin{array}{l}\text { Kuinka paikallisuus määrittyy hallinnollisten ja } \\
\text { rakenteellisten muutosten muokkaamilla } \\
\text { maaseutualueilla? } \\
\text { Miten paikallisen yhteys kunnalliseen, alueelliseen ja } \\
\text { kansalliseen hyvinvointipoliittiseen järjestelmään } \\
\text { konkretisoituu? }\end{array}$ \\
\hline $\begin{array}{l}\text { PALAUTEPROSESSIT: } \\
\text { Systeemin toimijoiden välillä on jatkuva } \\
\text { vuorovaikutus ja informaation vaihto. }\end{array}$ & $\begin{array}{l}\text { Paikallisten hyvinvointitarpeiden ja - } \\
\text { resurssien kokonaisuudesta pyritään } \\
\text { muodostamaan yhteisesti jaettua } \\
\text { ymmärrystä. }\end{array}$ & $\begin{array}{l}\text { Millaisia vuorovaikutuksen, yhteistyön ja } \\
\text { osallisuuden kanavia voidaan tunnistaa } \\
\text { paikallisyhteisön sisällä ja suhteessa ulkopuolisiin } \\
\text { toimijoihin kuten julkiseen palvelujärjestelmään? }\end{array}$ \\
\hline $\begin{array}{l}\text { KAAOKSEN REUNALLA: } \\
\text { Systeemi voi joutua pois tasapainosta, } \\
\text { mikäli se kohtaa toimintaansa } \\
\text { häiritseviä ilmiöitä tai ympäristön } \\
\text { epävakautta. }\end{array}$ & $\begin{array}{l}\text { Erilaiset kriisitilanteet heijastuvat } \\
\text { paikallistasoille eri tavoin. Paikallisten } \\
\text { hyvinvointijärjestelmien tavat/ } \\
\text { valmiudet vastata näihin ovat erilaiset. }\end{array}$ & $\begin{array}{l}\text { Mitä maaseudun paikallisyhteisöjä uhkaavia ilmiöitä } \\
\text { ja kehityskulkuja voidaan tunnistaa? } \\
\text { Millä tavoin paikallisyhteisöt reagoivat } \\
\text { vastaantuleviin haasteisiin? }\end{array}$ \\
\hline $\begin{array}{l}\text { MAHDOLLISUUKSIEN TILAT: } \\
\text { Tasapainottomuuden tila voi toimia } \\
\text { myös mahdollisuutena. }\end{array}$ & $\begin{array}{l}\text { Kriisi integroi eri sektoreita tiiviimpään } \\
\text { yhteistyöhön etsimään ratkaisuja } \\
\text { syntyneisiin hyvinvointivajeisiin. }\end{array}$ & $\begin{array}{l}\text { Millaisia vaihtoehtoisia tulevaisuuden } \\
\text { kehitysnäkymiä voidaan yhteistyössä tunnistaa? } \\
\text { Millaisia mahdollisuuksia näihin sisältyy? }\end{array}$ \\
\hline $\begin{array}{l}\text { POLKURIIPPUVUUS: } \\
\text { Valitessaan tietyn kehityssuunnan tai } \\
\text { polun systeemi on riippuvainen tästä } \\
\text { valinnastaan pitkälle tulevaisuuteen. }\end{array}$ & $\begin{array}{l}\text { Tehdyt strategiset valinnat määrittävät } \\
\text { miten paikallinen hyvinvointijärjestelmä } \\
\text { toimii ja mihin sen toiminta suuntautuu. }\end{array}$ & $\begin{array}{l}\text { Millaisia asioita maaseudun paikallisyhteisöt } \\
\text { tavoittelevat? Miten tavoitteita pyritään } \\
\text { saavuttamaan? }\end{array}$ \\
\hline $\begin{array}{l}\text { HISTORIA: } \\
\text { Systeemi on aina riippuvainen } \\
\text { historiastaan. }\end{array}$ & $\begin{array}{l}\text { Historia vaikuttaa paikallisen } \\
\text { hyvinvointijärjestelmän rakenteen ja } \\
\text { toiminnan muotoutumiseen. }\end{array}$ & $\begin{array}{l}\text { Millaisia erityispiirteitä maaseudun paikallisyhteisöt } \\
\text { ovat historian myötä saaneet? } \\
\text { Millainen on paikallinen toimintakulttuuri? Miten } \\
\text { paikallisyhteisöt ovat tottuneet toimimaan? }\end{array}$ \\
\hline $\begin{array}{l}\text { ITSEOHJAUTUVUUS: } \\
\text { Asiantuntijuus, keskinäinen riippuvuus, } \\
\text { palaute ja tulevaisuuteen } \\
\text { suuntautuneisuus luovat } \\
\text { itseohjautumista. }\end{array}$ & $\begin{array}{l}\text { Vuorovaikutussuhteiden kautta voidaan } \\
\text { rakentaa jaettua ymmärrystä } \\
\text { paikallisista tarpeista ja resursseista } \\
\text { sekä vaadittavista toimenpiteistä. }\end{array}$ & $\begin{array}{l}\text { Millaisia toimijaresursseja, kumppanuusmalleja ja } \\
\text { toimintamahdollisuuksia maaseudun } \\
\text { paikallisyhteisössä voidaan tunnistaa? } \\
\text { Millä tavoin toimijoiden välinen yhteistyö } \\
\text { organisoituu? }\end{array}$ \\
\hline $\begin{array}{l}\text { EMERGENSSI: } \\
\text { Prosessit, joissa muodostuu uusia } \\
\text { toimintatapoja tai -malleja. }\end{array}$ & $\begin{array}{l}\text { Dynaamisessa kokonaisuudessa syntyy } \\
\text { uudenlaisia tapoja tuottaa hyvinvointia; } \\
\text { paikallinen hyvinvointijärjestelmä } \\
\text { muotoutuu. }\end{array}$ & $\begin{array}{l}\text { Millaisia palveluja, hyvinvointi-innovaatioita ja } \\
\text { kumppanuusmalleja maaseudun paikallisyhteisöissä } \\
\text { syntyy? }\end{array}$ \\
\hline
\end{tabular}




\section{MaAseudun Paikallisten} HYVINVOINTIJÄRJESTELMIEN TULKINTAMALLI

Kompleksisuusajattelun avaamien näköalojen pohjalta lähdemme seuraavaksi kehittämään paikallisten hyvinvointijärjestelmien teoriaa siten, että se soveltuu paremmin myös maaseudun paikallisyhteisöjen hyvinvoinnin analyysiin. Teemme tämän paneutumalla aluksi tarkemmin edellä kuvatun analyysin myötä esiin nousseisiin alkuperäistä teoriaa täydentäviin ja laajentaviin ulottuvuuksiin.

Sosiaalisesti konstruoidun tilan ja yhteyksien kautta rakentuva paikallisuus

Brittiläisen maantieteilijän Doreen Masseyn (2008, 29-31) mukaan paikat ovat ensisijaisesti sosiaalisesti konstruoituja aikaan kiinnityviä tiloja, joiden ainutlaatuisuus syntyy menneisyyden, nykyisyyden, kulttuurin ja sosiaalisten suhteiden kokonaisuudesta. Paikat eivät ole staattisia tai toisistaan irrallisia, vaan niiden identiteetit muodostuvat suhteissa toisiin paikkoihin. Vaikka verkottuneessa maailmassa ihmiset ja heidän identiteettinsä eivät kiinnity vain tiettyyn maantieteelliseen alueeseen, luovat päivittäinen elinympäristö sekä tähän kytkeytyvät toiminnallisuudet ja vuorovaikutussuhteet myös fyysiseen ympäristöön kiinnittyvää paikkasidonnaisuutta (vrt. Byrne 2001). Suhteellisen yksinkertaiselta vaikuttava käsite "paikallinen" on todellisuudessa vaikeasti määrittyvä ja edellyttää sosiaalisten $\mathrm{ja}$ alueellisten prosessien sekoittumisen ymmärtämistä (Urryn 1995, 73).

Tietyllä maantieteellisellä alueella asuvien ihmisten paikallisyhteisyyt- tä muokkaa maaseutusosiologi Pertti Rannikon (2009) mukaan keskinäisen kanssakäymisen (interaktio) ja samaistumisen tunteen (identiteetti) ohella keskeisesti myös paikalliset instituutiot kuten palvelut ja yhdistykset. Fyysiseen ja sosiaaliseen ympäristöön kytkeytyvät arjen toiminnot sekä keskinäisiä sidoksia ylläpitävä toiminta vahvistavat paikallisyhteisyyttä ja rakentavat kuulumisen kokemusta sekä paikkaan että yhteisöön. Tästä hyviä esimerkkejä ovat aktiivinen kylätoiminta sekä oikeutuksen hakemiseksi tulkittavat prosessit maaseutuyhteisöjen taistellessa peruspalvelujensa säilymisen puolesta (ks. myös Kumpulainen 2018). Paikallisten hyvinvointijärjestelmien kontekstissa ei voidakaan sivuuttaa julkisen sektorin ja sen tuottamien peruspalvelujen merkitystä institutionaalisen rakenteen sekä toisaalta paikallisen ja kansallisen välisen yhteyden rakentumiselle. Palvelujen välityksellä julkisen sektorin toimijoille avautuu konkreettinen kosketuspinta paikallisyhteisön arkeen sekä mahdollisuuksia osallistua keskusteluun ja yhteisen ymmärryksen rakentamiseen paikallisen hyvinvointijärjestelmän sisältä päin, osana systeemiä.

Toisaalta on syytä pitää mielessä, että paikallisuus itsessään on jatkuvan sisäisen määrittelykamppailun kohteena eri toimijoilla ollessa erilaisia näkemyksiä siitä, mitä se on tai mitä sen tulisi olla (Rannikko 2009). Paikallisuuden määrittämistä haastaa paitsi yhteisöllisten rakenteiden - vuorovaikutussuhteiden ja instituutioiden - jatkuva muutos ja jopa mahdollinen purkautuminen, myös niiden muotoutuminen entistä enemmän ylipaikallisten yhteyksien kautta (vrt. Kumpulainen 2012b). Liikkuvan ja monipaikkaisen elämän- 
tavan yleistymisen myötä paikkojen ja ihmisten väliset verkostot ovat yhä avoimempia. Yhteisöjen limittyminen kytkee ihmisiä samanaikaisesti useisiin paikkoihin ja verkostoihin. (Rannikko 2016; Pitkänen ym. 2017.) Maaseudulle tyypillistä on vapaa-aikaan ja kausityöhön liittyvä monipaikkainen liikkuminen ja asuminen (Pitkänen \& Strandell 2018). Monipaikkaisuus kuvastaakin hyvin sitä, etteivät paikallisuus ja tähän kytkeytyvä yhteisöllisyys ole selkeärajaista, vaan monisyistä ja monin eri tavoin ympäröivään maailmaan sidoksissa olevaa. Hyvinvointijärjestelmien näkökulmasta tämä on sekä haaste että mahdollisuus: haaste koskien interaktiota ja palvelujen järjestämistä, mutta mahdollisuus edistäen alueiden ja ihmisten välistä vuorovaikutusta. Tämä luo edellytyksiä niin uuden tiedon ja osaamisen omaksumiselle kuin uusien toimija- ja yhteistyöresurssien syntymiselle.

\section{Kokonaisvaltainen hyvinvointikäsitys}

Paikallisuuden tavoin myös hyvinvointiin kytkeytyvät kysymykset ovat moniulotteisia ja monin tavoin toisiinsa sekä toimintaympäristöön yhteen kietoutuvia. Tästä klassinen esimerkki on useilla maaseutualueilla konkretisoituva ikääntyvän ja vähenevän väestön, ohenevan palvelurakenteen sekä pitkien välimatkojen muodostama vaikea yhtälö. Hyvinvoinnin muotoutumista ei näin ollen ole mielekästä lähestyä kapea-alaisesti yksittäiseen politiikkasektoriin tai väestöryhmään keskittyen. Tarve uudenlaisen lähestymistavan omaksumiseen kumpuaa myös inhimillisen hyvinvoinnin ja elinympäristön välisen vahvan keskinäisriippuvuuden ymmärtämisestä. Kyse ei ole pelkästään inhimillisistä tarpeista, vaan myös todellisista mahdollisuuksista tyydyttää näitä kestävällä tavalla.

Kokonaisvaltaisen hyvinvointikäsityksen kehyksenä toimivat kestävän hyvinvoinnin universaalit ulottuvuudet. Hyvinvoinnin tutkijat Tuula Helne ja Tuuli Hirvilammi (2015) ovat sosiologi Erik Allardtin (1976, 39-49; 1993) hyvinvointiteoriaa mukaillen jäsentäneet kestävää hyvinvointia neljän ulottuvuuden kautta. Nämä ovat kohtuullinen elintaso (having), merkitykselliset suhteet (loving), itsensä toteuttaminen ja elävä läsnäolo (being) sekä mielekäs ja vastuullinen toiminta (doing). Kolme ensimmäistä konkretisoituvat tyydyttävinä elinoloina sisältäen palvelujen saatavuuden, mahdollisuuden kokea osallisuutta ja sosiaalista yhteenkuuluvuutta, toteuttaa itselle merkityksellisiä asioita sekä vaikuttaa omaa elinympäristöä ja laajemmin yhteiskuntaa koskeviin asioihin. Vastuullisuutta korostava doing-ulottuvuus suuntaa huomion tavoiteltavan elintason kohtuullisuuteen sekä siihen, että tapa, jolla nykyhetken tarpeet tyydytetään, ei vie tulevilta sukupolvilta heidän mahdollisuuksiaan tyydyttää omia tarpeitaan (vrt. WCED 1987). Hyvinvoinnin tavoittelussa tulee ottaa huomioon myös ne seuraukset, joita sillä on ekologisesti, sosiaalisesti ja taloudellisesti kestävälle kehitykselle niin paikallisesti kuin laajemmin globaalissa perspektiivissä.

Hyvinvointitarpeet ja niihin vastaaminen konkretisoituvat viime kädessä ihmisten arjessa kysymykseen siitä, miten saavuttaa hyvä elämä. Tämän tarkasteluun välineitä tarjoaa taloustieteilijä Amartya Senin (1999, 98-100) toimintamahdollisuuksia korostava lähestymistapa (capability approach), joka 
suuntaa huomion ihmisen todellisiin mahdollisuuksiin hyödyntää henkilökohtaisia, sosiaalisia sekä yhteiskunnallisia resursseja hyvinvoinnin tavoittelussa. Sillä, miten ihmiset kokevat yhteiskunnallisten rakenteiden, paikallisten elinolosuhteiden sekä henkilökohtaisten ja yhteisöllisten resurssien tukevan arjen sujuvuutta, on keskeinen merkitys hyvinvoinnin rakentumiselle (Raijas 2011). Hyvinvoinnin kokemuksellisen ulottuvuuden merkityksellisyyttä korostaa myös kestävyysdiskurssin myötä esiin noussut tarve määritellä hyvinvointikäsitystä uudelleen. Useat tutkimukset (esim. Bodman 2019; YliViikari \& Lilja 2016) ovat esimerkiksi osoittaneet, että maaseutuasumista luonnehtiva luonnon läheisyys sekä ihmisten kiinteä luontosuhde ovat merkittäviä hyvinvoinnin lähteitä. Hyvinvointia määrittelevissä teoreettisissa keskusteluissa nämä eivät kuitenkaan vielä juuri näy.

Olemme koonneet kokonaisvaltaisen hyvinvointikäsityksen keskeiset elementit Kuvioon 2. Sen lähtökohtana ovat arjessa konkretisoituvat mahdollisuudet hyvään elämään, mitä kehystää ymmärrys ihmisen ja luonnon välisestä suhteesta ja keskinäisriippuvuudesta. Kaiken perustana toimivat hyvinvointia ylläpitävät ekosysteemit, jotka sekä luovat perustan inhimillisten hyvinvointitarpeiden tyydytykseen että asettavat tälle selkeät rajat. (ks. Helne \& Hirvilammi 2015.)

Vuorovaikutuksen, yhteistyön ja osallisuuden kanavat

Paikallisten hyvinvointijärjestelmien analyysissä keskeisessä roolissa on eri

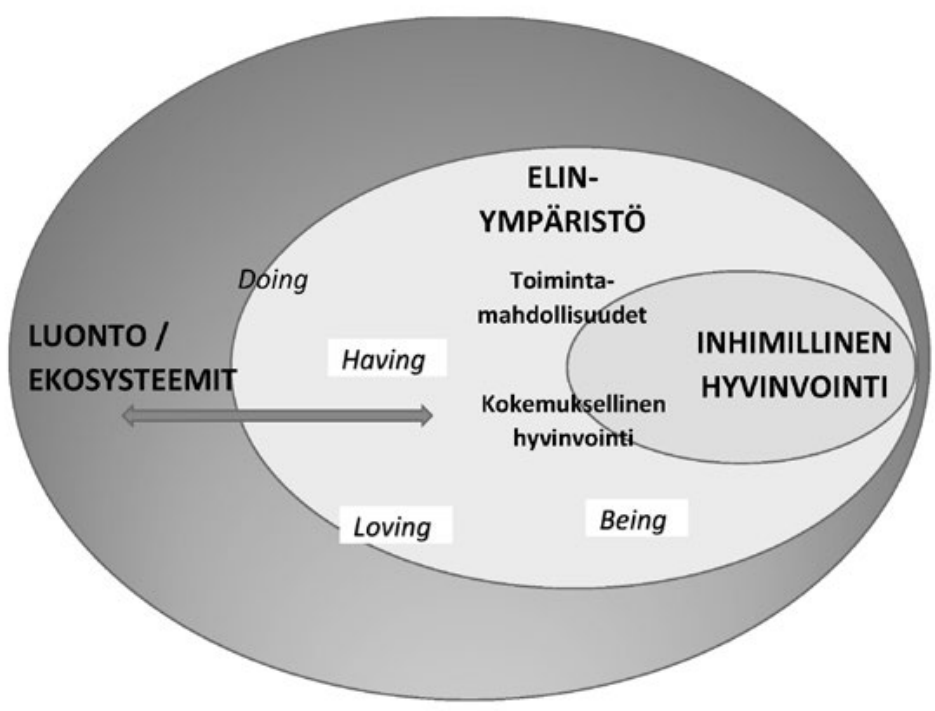

Kuvio 2. Kokonaisvaltainen näkökulma hyvinvointiin (mukaillen ja täydentäen Helne \& Hirvilammi 2015). 
toimijoiden keskinäinen vuorovaikutus ja yhteistyö, jota säätelevät niin ideologisella tasolla vaikuttavat ajattelumallit kuin konkreettiset rakenteet ja toimintakäytännöt. Kuten tunnistettua, julkisen sektorin ja kansalaisyhteiskunnan väliselle yhteistyölle voidaan asettaa hyvin monenlaisia odotuksia. Kolmannen sektorin tutkija Adalbert Evers (2009) kiteyttää nämä neljään myös hyvinvointivaltion kronologista kehitystä heijastelevaan diskurssiin. Perinteisessä hyvinvointivaltiollisessa ajattelussa (traditional welfarism) julkiset palvelut mielletään sosiaalisiksi oikeuksiksi, joita hallitaan demokraattisen järjestelmän keinoin. Osallisuutta (participation) korostava diskurssi painottaa puolestaan kansalaisyhteiskunnan merkitystä julkista sektoria tukevana ja täydentävänä, mikä peräänkuuluttaa kansalaisten aktiivista osallistumista palvelujen kehittämiseen ja tuottamiseen (co-production). Kuluttajadiskurssissa (consumerism) keskiöön nousevat kansalaisten yksilölliset valinnanmahdollisuudet sekä niiden turvaaminen monimuotoisilla hyvinvointipalvelujen markkinoilla. Kansalaisyhteiskunnan organisaatioiden ensisijainen rooli on toimia kansalaiskuluttajien edunvalvojina, mutta ne voivat myös tuottaa palveluja. Viimeisten vuosien aikana suomalaista hyvinvointipolitiikkaa on hallinnut aktivoiva sosiaalinen investointivaltio -diskurssi (activating social investment state). Se edustaa eräänlaista paluuta valtiokeskeiseen ajatteluun, kuitenkin niin, että kansalaisosallisuus nousee oikeuksien sijaan esiin velvollisuuksina ja aktiivisuuden vaatimuksena. "Kansalaishyveiden" - kuten demokraattisissa vaaleissa äänestäminen - sijaan aktiivisuusodotukset kohdistuvat siihen, että kansalaiset ottavat selkeästi vastuuta omasta hyvinvoinnistaan. Eversin jäsennys on luonnollisesti pelkistetty kiteytys niistä erilaisista muodoista ja merkityksistä, joita kansalaiset ja kansalaisyhteiskunnan organisaatiot voivat kansallisen hyvinvointimallin kontekstissa saada. Kulloinkin vallitsevan diskurssin tiedostaminen auttaa kuitenkin ymmärtämään niitä odotuksia, joita myös paikallisyhteisöihin kohdistuu.

Paikallisten hyvinvointijärjestelmien sisäisen vuorovaikutuksen analyysin kannalta on oleellista tunnistaa, millaisia eri toimijoiden ja yhteisön jäsenten keskinäistä kohtaamista ja vuoropuhelua edistäviä rakenteita ja toimintakäytäntöjä on olemassa. Näihin kuuluvat paikalliset yhdistykset ja epäviralliset yhteisöt, kohtaamispaikat kuten kylätalot ja torit, keskustelutilaisuuksien ja yhteisten juhlien kaltaiset yhteisölliset tapahtumat sekä keskinäistä tiedonvaihtoa edistävät kanavat, esimerkkinä paikallislehti ja paikallisyhteisön oma Facebook-ryhmä (vrt. Matthies 2013). Nämä kaikki tarjoavat tiloja ja väyliä, joiden kautta voidaan rakentaa yhteistä tulkintaa paikalliseen hyvinvointiin kytkeytyvistä tarpeista sekä kehittää niitä koskevia ratkaisuja. Parhaimmillaan kyse on yhteisöllistä kiinteyttä vahvistavasta toiminnasta, joka jo itsessään on merkittävä hyvinvointiresurssi.

Paikallistason ja kansallista hyvinvointipolitiikkaa ilmentävän julkisen palvelujärjestelmän välisen vuorovaikutuksen tarkastelussa oleellista on kiinnittää huomiota siihen, kuinka se lisää keskinäistä ymmärrystä eri osapuolten toimintaan kytkeytyvistä realiteeteista. Tämä on erityinen haaste maaseudulla, josta julkinen palvelujärjestelmä on hallinnollisesti etääntymässä. Jotta voi- 
daan ymmärtää, kuinka kansalaisten osallisuus ja vaikuttamismahdollisuudet julkisessa palvelujärjestelmässä toteutuvat, tulee huomio suunnata kolmelle eri tasolle (Kattilakoski ym. 2011). Peruslähtökohtana toimivat perinteiset demokraattisen järjestelmän kanavat, mutta hallinnon etääntyessä yhä kauemmaksi maaseudun arjesta tarvitaan rinnalle myös erilaisia alue-, asukas- ja asiakasryhmäkohtaisia vaikuttamistoimielimiä. Toista tasoa edustaa päivittäisissä kohtaamisissa todentuva toimintakulttuuri, jolla viittaamme siihen, että niin yksittäisissä palvelutapahtumissa kuin toiminnan suunnittelussa kyetään ottamaan huomioon alueellinen ulottuvuus. Kolmanneksi väyliä vuorovaikutukselle tarjoaa paikallinen palvelutuotanto sekä tähän liittyvä yhteistyö. Muodosta ja tavasta riippumatta paikallisen hyvinvointijärjestelmän kontekstissa oleellista on, että paikallisen ja julkisen keskinäistä vuorovaikutusta arvioidaan nimenomaan paikallisesta näkökulmasta. Toimivan ja yhteistä todellisuutta rakentavan vuorovaikutuksen kriteerinä voidaan pitää vastavuoroisuutta, pelkkä yksisuuntainen tiedottaminen tai muodollisten vaikuttamiskanavien olemassaolo eivät vielä riitä.

\section{Tulevaisuusnäkymät}

Jatkuvassa muutoksessa olevassa maailmassa maaseudun paikallisyhteisöjen kyky ennakoida ja tunnistaa näköpiirissä olevia kehityskulkuja on merkityksellistä sekä niiden toiminnan että ylipäätään olemassaolon kannalta. Toisaalta samalla tavoin merkityksellistä on, millaisia tulkintoja paikallisyhteisöt näistä muutoksista ja ilmiöistä tekevät, sekä millaisiksi ne arvioivat omat voi- mavaransa ja mahdollisuutensa toimia suhteessa niihin. On kuitenkin tärkeä pitää mielessä, että kyse ei ole pelkästään resilienssistä - kyvystä sopeutua - vaan myös siitä, millaisia toimintaedellytyksiä kansallinen ja EU-tason politiikka erilaisille paikallisyhteisöille tarjoavat (resourcefullness) (MacKinnon \& Derickson 2012).

Maaseutupolitiikan tutkija David Freshwater (2015) jäsentää maaseutuyhteisöjen keskeiset tulevaisuuden haasteet luonnonmullistuksiin, poliittisessa ilmapiirissä tapahtuviin muutoksiin, talouden heikkenemiseen sekä turvattomuuden lisääntymiseen. Kukin näistä neljästä kategoriasta pitää sisällään tapahtumia tai kehityskulkuja, jotka voivat olla luonteeltaan ja seurauksiltaan positiivisia tai negatiivisia. Eri kategoriat ovat myös toisiinsa tiiviisti sidoksissa, jolloin yhdellä osa-alueella tapahtuvat muutokset vähintäänkin heijastuvat muihin. Laajat ja merkittävät muutokset voivat johtaa eräänlaiseen dominoefektiin, jonka seurauksena koko tulevaisuus näyttäytyy uudessa valossa.Viime aikoina tällaisiksi tekijöiksi ovat nousseet luonnonmullistusten kategoriaan laskettava ilmastonmuutos ja turvattomuutta lisäävä Covid-19 pandemia, jotka pakottavat ihmiskuntaa arvioimaan uudelleen tapaansa toimia ja elää. Tulevaisuusperspektiivin ristiriitaisesta luonteesta kertoo osaltaan se, että puhujasta riippuen maaseutu nähdään ilmastonmuutoskeskustelussa joko ongelmana tai sen ratkaisuna, ja vastaavasti koronapandemian vaikutukset maaseudun elinvoimaa heikentävinä tai vahvistavina.

Politiikan sekä talouden kentillä tapahtuneiden kehityskulkujen pers- 
pektiivistä maaseutualueiden tulevaisuus näyttäytyy varsin haasteellisena. Niukkenevan julkisen talouden kehyksessä hyvinvointipoliittista ajattelua ohjaa vahvasti talouspoliittisiin lähtökohtiin sitoutuvat tuottavuuden ja tehokkuuden pyrkimykset. Hyvinvointipalvelujen uudistamiseen tähtäävissä reformeissa tämä ilmenee keskittämiseen, karsimiseen sekä markkina-ajattelun vahvistamiseen tähtäävänä kehityssuuntana (Julkunen 2017). Yhdessä yhteiskunnallisen infrastruktuurin ohenemisen kanssa tämä asettaa maaseutuyhteisöjä haavoittuvaan asemaan palvelujen saavutettavuuden suhteen sekä luo uhkakuvia yhteiskun- nallisen ja alueellisen eriarvoisuuden syvenemisestä.

\section{MaAseudun Paikallisten HYVINVOINTIJÄRJESTELMIEN TEOREETTINEN TULKINTAMALLI}

Olemme jäsentäneet artikkelissa maaseudun paikallisyhteisöjen hyvinvoinnin muotoutumiseen vaikuttavia tekijöitä. Lähtökohtanamme on toiminut (Mingione \& Oberti 2003; Andreotti ym. 2012; Andreotti \& Mingione 2013 ja 2016) paikallisten hyvinvointijärjestelmien teoria, jota olemme laajentaneet ja syventäneet kompleksisuus-

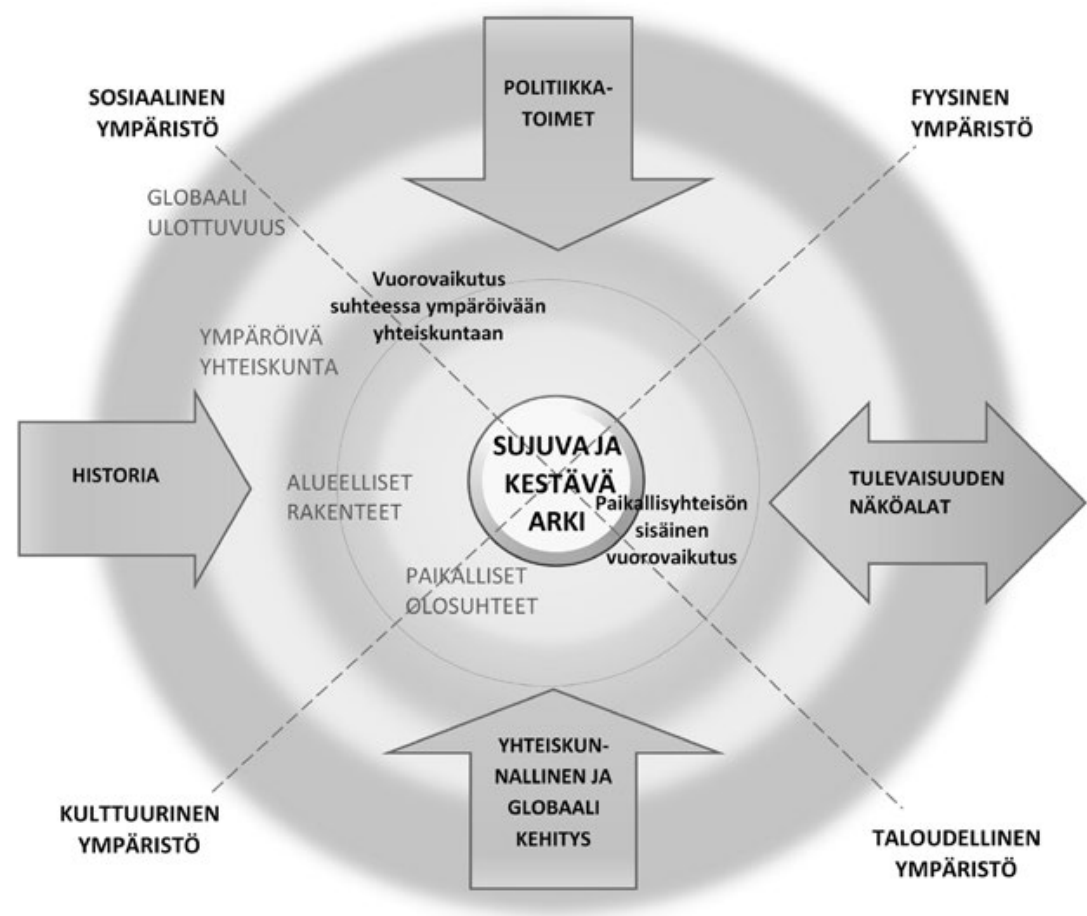

Kuvio 3. Maaseudun paikallisten hyvinvointijärjestelmien teoreettinen tulkintamalli 
ajattelun avaamien näköalojen kautta maaseutukontekstiin soveltuvaksi.

Maaseudun paikallisten hyvinvointijärjestelmien kontekstissa määrittyvän paikallisuuden ymmärrämme hallinnollisten rajojen sijaan maantieteellisen ulottuvuuden, institutionaalisten rakenteiden ja vuorovaikutussuhteiden muodostamana kokonaisuutena $(\mathrm{Ku}-$ vio 3). Siihen, millaisen muodon paikallinen hyvinvointijärjestelmä saa ja millaiseksi sen toiminta muotoutuu, vaikuttavat olennaisesti sitä kehystävät ja läpileikkaavat fyysiset, sosiaaliset, taloudelliset ja kulttuuriset tekijät. Näihin sisältyvät luonto- ja rakennettu ympäristö, sosiodemografiset piirteet, työpaikka-, elinkeino- ja palvelurakenne sekä yhteisesti jaettuja arvoja ja perinteitä. Lisäksi paikalliset hyvinvointijärjestelmät muotoutuvat aina suhteessa laajempaan yhteiskunnalliseen kontekstiin ollen osa siinä vaikuttavien kansallisten ja globaalien kehityskulkujen ja politiikkatoimien vaikutuspiiriä. Hyvinvoinnin näkökulmasta näistä luonnollisesti keskeisin on kansallinen hyvinvointipolitiikka ja sen kulloisenakin aikana saama muoto.

Alkuperäisen teorian sektorilähtöisestä ja yksittäisiin väestöryhmiin keskittyvästä tarkastelusta poiketen lähestymme mallissa paikallistason hyvinvointia kokonaisvaltaisen hyvinvointikäsityksen viitekehyksestä. Tarkastelun keskiöön asettuu tällöin yleinen arjen sujuvuus: millaiset ovat yhteisön ja sen jäsenten mahdollisuudet tyydyttää kohtuulliseen elintasoon, sosiaaliseen yhteenkuuluvuuteen sekä itsensä toteuttamiseen liittyvät perustarpeet. Kokonaisvaltainen hyvinvointikäsitys ei kuitenkaan rajoitu pelkästään inhimillisiin perus- tarpeisiin, vaan se avartaa näkökulmaa kestävää kehitystä koskeviin keskusteluihin. Olennaista on, millaisia vaikutuksia hyvinvoinnin tavoitteluun liittyvillä toimilla on laajemmin planetaariseen kehitykseen ja ekosysteemien toimintaan.

Nykyisyyden ja historian myötä kehittyneiden erityispiirteiden ja toimintatapojen ohella maaseudun paikallisten hyvinvointijärjestelmien rakenteeseen ja toimintaan vaikuttavat tulevaisuusperspektiivin kautta avautuvat näköalat - mahdollisuudet ja mahdottomuudet. Edellytyksiä vaihtoehtoisten kehityspolkujen tunnistamiseen luo eri toimijatahojen ja -tasojen välinen vuoropuhelu. Sen kautta on mahdollista rakentaa yhteistä ymmärrys paikallisista tarpeista ja niihin vastaamiseksi käytettävissä olevista yhteisöllisistä resursseista. Vuoropuhelun rakentuminen paikallistasolta suhteessa alueellisiin ja kansallisiin instituutioihin, toimijoihin sekä poliittiseen päätöksentekoon avaa mahdollisuuksia dialogille, jossa erilaiset tarpeet ja resurssit asettuvat yhteisen tarkastelun kohteeksi.

\section{LOPUKSI}

Kehittämämme maaseudun paikallisten hyvinvointijärjestelmien tulkintamalli tarjoaa hyvinvointiteoreettiseen keskusteluun hyvinvoinnin monimuotoisuutta ja kokonaisvaltaisuutta korostavan lähestymistavan. Tilanteessa, jossa hyvinvointivaltiolle ollaan etsimässä uudenlaista perustaa ja rakennetta, on tärkeä ymmärtää niitä paikallistason mekanismeja, joiden puitteissa hyvinvointitarpeet sekä -resurssit syntyvät ja kansallinen hyvinvointipolitiikka saa 
konkreettisen muodon. Kehitys ei tapahdu koskaan vain ylhäältä alas vaan myös alhaalta ylös - erilaisten näkökulmien ja vuorovaikutussuhteiden leikkauspisteessä.

Alkuperäisen paikallisten hyvinvointijärjestelmien teorian lähtökohtana olivat kaupunkimaiset olosuhteet. Maaseutunäkökulman ja kompleksisuusajattelun myötä olemme laajentaneet mallia neljällä ulottuvuudella. Näistä etenkin eri toimijoiden keskinäisen vuorovaikutuksen muotoutumiseen sekä kokonaisvaltaiseen hyvinvointiin liittyvät kysymykset ovat niitä, joihin on syytä suunnata huomiota myös mallia kaupunkikontekstiin sovellettaessa. Mallin hyödyntämisessä sekä laajemmin sen jatkokehittämisessä seuraava tärkeä askel on miettiä sitä, millaisin tutkimusmenetelmin eri ulottuvuuksiin voidaan päästä käsiksi. Pitäen mielessä, että paikallisten hyvinvointijärjestelmien tulkintamallin keskeinen ajatus on tuottaa tietoa kansallisen ja paikallisen hyvinvointipolitiikan leikkauspisteestä, näemme, että ratkaisua tulisi lähteä etsimään osallistavan toimintatutkimuksen menetelmistä. Niiden tuominen tilastollisten $\mathrm{ja}$ indikaattoripohjaisten aineistojen rinnalle luo kansalaisille ja paikallisyhteisöille mahdollisuuden osallistua aktiivisesti yhdessä julkisten toimijoiden ja tutkijoiden kanssa niin hyvinvointitiedon tuottamiseen kuin sen tulkintaan.

\section{KirJallisuUs}

Allardt, Erik (1976) Hyvinvoinnin ulottuvuuksia. Helsinki: WSOY.

Allardt, Erik (1993) Having, loving, being: an alternative to the Swedish model of welfare research. Teok- sessa Martha Nussbaum \& Amartya Sen (toim.) The quality of life. Oxford Clarendon Press, 88-94. https://doi. org/10.1093/0198287976.003.0008

Andreotti, Alberta \& Mingione, Enzo (2013) The city as local welfare system. Teoksessa Naomi Carmon \& Susan S. Fainstein (toim.) Policy, planning and people: promoting justice in urban development. The city in the twenty-first century. Philadelphia: University of Pennsylvania Press, 224-241. https://doi. org/10.9783/9780812207965.224

Andreotti, Alberta \& Mingione, Enzo (2016) Local welfare systems in $\mathrm{Eu}-$ rope and the economic crisis. European Urban and Regional Studies 23 (3), 252-266. https://doi. org/10.1177/0969776414557191

Andreotti, Alberta \& Mingione, Enzo \& Polizzi, Emanuele (2012) Local welfare systems: a challenge for social cohesion. Urban Studies 49 (9),1925-1940.https:// doi.org/10.1177/0042098012444884

Beresford, Peter (2010) Public partnerships, governance and user involvement: a service users' perspective. International Journal of Consumer Studies, 34 (5), 495-502. https://doi.org/10.1111/ j.1470-6431.2010.00905.x

Bock, Bettina B. (2016) Rural marginalisation and the role of social innovation; a turn towards nexogenous development and rural reconnection. Sociologia Ruralis, 56 (4), 552-573. https://doi. org/10.1111/soru.12119

Bodman, Ghita (2019) Leva ett med naturen - "Dammråttor kan man ju ge namn åt om man vill". Åbo Akademis forlag: Åbo Akademi University Press.

Byrne, David (1998) Complexity theory and the social sciences. London: Routledge.

Byrne, David (2001) Understanding the Urban. Basingstoke: Palgrave. https:// doi.org/10.1007/978-1-137-18512-9

Byrne, David (2005) Complexity, configurations and cases. Theory, Culture \& Society 22 (5), 95-111. https://doi. org/10.1177/0263276405057194

Cilliers, Paul (1998) Complexity and postmodernism. London: Routledge.

Esping-Andersen, Gosta (1990) The three worlds of welfare capitalism. Oxford: 
Polity Press.

Evers, Adalbert (2009) Civicness and civility: their meanings for social services. Voluntas 20 (3), 239-259. https://doi. org/10.1007/s11266-009-9088-x

Evers, Adalbert \& Guillemard, Anne-Marie (2012) Reconfiguring welfare and reshaping citizenship". Teoksessa Adalbert Evers \& Anne-Marie Guillemard (toim.) Social policy and citizenship: the changing landscape. Oxford: Oxford University Press,359-388.https://doi.org/10.1093/ acprof:oso/9780199754045.003.0071

Freshwater, David (2015) Vulnerability and resilience: Two dimensions of rurality. Sociologia Ruralis, 55 (4), 497-515. https://doi.org/10.1111/soru.12090

Heinonen, Jari (2019) 20-luvun hyvinvointimalli. Helsinki: Into Kustannus $\mathrm{Oy}$.

Helminen, Ville \& Nurmio, Kimmo \& Rehunen, Antti \& Ristimäki, Mika \& Oinonen, Kari \& Tiitu, Maija \& Kotavaara, Ossi \& Antikainen, Harri \& Rusanen, Jarmo (2014) Kaupunki-maaseutu alueluokitus. Paikkatietoihin perustuvan alueluokituksen muodostamisperiaatteet. Suomen ympäristökeskuksen raportteja $25 / 2014$. Suomen ympäristökeskus.

Helne, Tuula \& Hirvilammi, Tuuli (2015) Wellbeing and sustainability: A relational approach. Sustainable Development 23 (3), 167-175. https://doi.org/10.1002/ sd.1581

Hvinden, Bjorn \& Johansson, Håkan (toim.) (2007) Citizenship in nordic welfare states: dynamics of choice, duties and participation in a changing Europe. London: Routledge. https://doi. org/10.4324/9780203933527

Hämeenaho, Pilvi (2012) Palvelujen saavutettavuus harvaan asutulla maaseudulla. Esimerkkinä lasten päivähoitopalvelut. Janus 20 (1), 32-46.

Jalonen, Harri (2006) Kompleksisuusajattelu yhteiskuntatieteissä. Politiikka 48 (2), 115-125.

Julkunen, Raija (2017) Muuttuvat hyvinvointivaltiot: eurooppalaiset hyvinvointivaltiot reformoitavina. Jyväskylä: Jyväskylän yliopisto, SoPhi.

Karvonen, Sakari (2015) Hyvinvoinnin alue-erojen jäljillä: politiikkaa vai paikallista kehittämistä? Teoksessa Antti Kaihovaara (toim.): Jakolinjojen Suomi. Kalevi
Sorsa -säätiö, 119-140.

Kauppinen, Timo M. \& Karvonen, Sakari (2014) Hyvinvoinnin puutteet asuinpaikan maaseutumaisuuden mukaan. Teoksessa Marja Vaarama, Sakari Karvonen, Laura Kestilä, Pasi Moisio \& Anu Muuri (toim.) Suomalaisten hyvinvointi 2014. Tampere: Terveyden ja hyvinvoinnin laitos, 80-97.

Kattilakoski, Mari \& Rantamäki, Niina (2016) Maaseudun paikalliset hyvinvointijärjestelmät kansallisen hyvinvointipolitiikan kontekstissa. Teoksessa Ilkka Luoto, Mari Kattilakoski \& Peter Backa(toim.): Näkökulmana paikkaperustainen yhteiskunta. Työ- ja elinkeinoministeriön julkaisuja. Alueiden kehittäminen 25/2016. Helsinki: Työ ja elinkeinoministeriö, 89-108.

Kattilakoski, Mari (2015) Kylien yhteisöllinen palvelutuotanto - paikallista hallintaa palvelujärjestelmämuutoksessa. Maaseudun uusi aika 23 (1), 19-36.

Kattilakoski, Mari \& Matthies, Aila-Leena \& Rantamäki, Niina (2011) Kansalaisosallistuminen maaseudun hyvinvointipalveluissa. Maaseudun uusi aika 19 (2), 5-19.

Kivelä, Päivi (2014) Syrjässä syrjäytyneet. Pelon sosiaalipolitiikka ja verkostoyhteistyön mahdollisuudet maaseudulla. Sininauhaliitto.

Kumpulainen, Kaisu (2012a) Kylätoiminta ja aktiivisen kylän tuottaminen. Jyväskylä Studies in Education, Psychology and Social Research 457. Jyväskylä: Jyväskylän yliopisto.

Kumpulainen, Kaisu (2012b) Kylä sosiaalisena tilana - Henri Lefebvren sosiaalisen tilan teoria kylän määrittelyn välineenä. Maaseudun uusi aika 20 (3), 5-13.

Kumpulainen, Kaisu (2014) Kun pienestä kunnasta tulee kylä. Kuntaliitosten vaikutukset maaseutuyhteisöissä. Työ- ja elinkeinoministeriön julkaisuja. Alueiden kehittäminen 33/2014. Helsinki: Työ- ja elinkeinoministeriö.

Kumpulainen, Kaisu (2018) Kylät tulevaisuuden paikallisyhteisöinä. Maaseudun uusi aika 26 (2-3), 55-65.

Kröger, Teppo (2017) Sosiaali- ja terveyspalvelujen reformaatio. Janus 25 (2), 160-165.

Leinamo, Kari (2010) Yhdeksän hyvää ja 
kymmenen kaunista. Vuosina 20012009 toteutettujen maaseutu-kaupunki -kuntaliitosten tarkastelua. Vaasa: Vaasan yliopisto, Levón-instituutti.

MacKinnon, Danny, \& Derickson, Kate (2012) From resilience to resourcefulness: A critique of resilience policy and activism. Progress in Human Geography 37 (2), 253-270. https://doi. org $/ 10.1177 / 0309132512454775$

Massey, Doreen (2008) Samanaikainen tila. Tampere:Vastapaino.

Matthies, Aila-Leena (2013) Hyvät käytänteet - työkaluja osallisuuden ja yhteisöllisyyden tukemiseen. Teoksessa Aila-Leena Matthies \& Niina Rantamäki (toim.) Hyvinvointitalkoot - Miten kuntalaisten osallistuminen tukee palveluita. Jyväskylän yliopisto, Kokkolan yliopistokeskus Chydenius, 60-66.

Matthies, Aila-Leena (2014) Sosiaalihuollon ja kansalaisyhteiskunnan suhde sivistyneen demokratian peilinä. Teoksessa Riitta Haverinen, Marjo Kuronen \& Tarja Pösö (toim.) Suomalaisen sosiaalihuollon tila ja tulevaisuus. Tampere:Vastapaino, 42-61.

Matthies, Aila-Leena \& Kattilakoski, Mari \& Rantamäki, Niina (2011a) Citizens' participation and community orientation - indicators of social sustainability of rural welfare services. Nordic Social Work Research, 1 (2), 125-139. https://doi.org /10.1080/2156857X.2011.613575

Matthies, Aila-Leena \& Kattilakoski, Mari \& Rantamäki, Niina (2011b): Maaseudun hyvinvointipalvelujen kehittäminen kansalaisosallistumisen ja yhteisöllisyyden pohjalta. KAMPA-hankkeen Tutkimusja kehittämisraportti I. Maaseutupolitiikan yhteistyöryhmän julkaisuja 9/2011. Maaseutupolitiikan yhteistyöryhmä.

Matthies, Aila-Leena \& Rantamäki, Niina (toim.) (2013) Hyvinvointitalkoot - Miten kuntalaisten osallistuminen tukee palveluita. Jyväskylä: Jyväskylän yliopisto, Kokkolan yliopistokeskus Chydenius.

Mingione, Enzo \& Oberti, Marco (2003) The struggle against social exclusion at the local level. Diversity and convergence in European cities. European Journal of Spatial Development 1 (1), 1-23.

Moisio, Sami (2012) Valtio, alue, politiikka. Suomen tilasuhteiden sääntely toisesta maailmansodasta nykypäivään. Tampere: Vastapaino.

Möttönen, Sakari \& Niemelä, Jorma (2005) The public and the third sector: new forms of cooperation. Jyväskylä: PSPublishing.

Pestoff, Victor \& Brandsen, Taco \& Verschuere, Bram (toim.) (2015) New public governance, the third sector and co-production. London/New York: Routledge.

Pohjola, Anneli (2017) Sote-uudistus muuttuvan yhteiskuntapolitiikan puristuksessa. Janus 25 (2), 171-175.

Pitkänen, Kati \& Strandell, Anna (2018) Suomalaisen maaseudun monipaikkaisen asumisen muodot ja tulevaisuuden kehitys. Maaseudun uusi aika 26 (2-3), 6-23.

Pitkänen, Kati \& Sireni, Maarit \& Rannikko, Pertti \& Tuulentie, Seija \& Hiltunen, Mervi J. (2017) Temporary mobilities regenerating rural places. Case studies from northern and eastern Finland. Journal of Rural \& Community Development 12 (2-3), 93-113.

Puustinen, Alisa \& Jalonen, Harri (2020) Kompleksisuusajattelu - ymmärtämistä edistävä uusi lähestymistapa vai vanhaa viiniä uudessa pullossa? Teoksessa Pirkko Vartiainen \& Harri Raisio (toim.) Johtaminen kompleksisessa maailmassa - Viisautta pirullisten ongelmien kohtaamiseen. Helsinki: Gaudeamus, 15-36.

Raijas, Anu (2011) Arjen hyvinvointi. Teoksessa Juho Saari (toim.) Hyvinvointi - Suomalaisen yhteiskunnan perusta. Helsinki: Gaudeamus, 243-263.

Rannikko, Pertti (2009) Kylä kaupungin laidaksi: Autoetnografinen tutkimus paikallisyhteisöjen identiteettien liikkeistä. Maaseudun uusi aika 17 (1), 5-19.

Rannikko, Pertti (2016) Täyttyvä syrjäseutu. Teoksessa Pertti Rannikko \& Maarit Sireni (toim.) Kotona, kylässä, liikkeellä. Sivakka ja Rasimäki arjen ja mielen tiloina. Helsinki: Suomalaisen kirjallisuuden seura, 209-239.

Rantamäki, Niina (2017) Co-production in the context of Finnish social services and health care: a challenge and a possibility for a new kind of democracy. Voluntas 28 (1), 248-264. https://doi. org/10.1007/s11266-016-9785-1

Rantamäki, Niina \& Kattilakoski, Mari (2017) Local welfare systems in rural 
Finland as a representation of sustainable development. Teoksessa Aila-Leena Matthies \& Kati Närhi (toim.) The ecosocial transition of societies. The contribution of social work and social policy. London: Routledge, 174-189.

Rantamäki, Niina \& Kattilakoski, Mari (2019) On the trail of local welfare innovations in rural Finland. Regional Science Policy \& Practice 11 (2), 329-343. https://doi.org/10.1111/rsp3.12213

Saari, Juho (2011) Hyvinvoinnin kentät. Teoksessa Juho Saari (toim.) Hyvinvointi - Suomalaisen yhteiskunnan perusta. Helsinki: Gaudeamus, 33-78.

Saarinen, Arttu \& Airio, Ilpo \& Kaikkonen, Risto \& Luoma, Minna-Liisa (2013) Onnellisuus erityyppisillä asuinalueilla, Yhteiskuntapolitiikka 78 (5), 520-532.

Saarsalmi, Perttu \& Karvonen, Sakari \& Kauppinen,Timo M. \& Koskela,Timo \& Murto,Jukka \& Kaikkonen, Risto (2017) Kaupunki-maaseutuluokituksen mukaisten terveys- ja hyvinvointierojen vaihtelu maan eri osissa. Yhteiskuntapolitiikka 82 (2), 188-199.

Sen, Amartya (1999) Commodities and capabilities. Oxford: Oxford University Press. (First Edition Published in 1987.)

Ståhle, Pirjo (2004) Itseuudistumisen dynamiikka - systeemiajattelu kehitysprosessien ymmärtämisen perustana. Teoksessa Markku Sotarauta \& Kati-Jasmin Kosonen (toim.) Näkymätön näkyväksi: Avauksia kehitysprosessien näkymättömän dynamiikan tutkimukseen. Tampere: University Press, 1-21.
Tedre, Silva \& Pulkkinen, Anneli (2010) Vanhuksen paikka maaseudulla - vanhustyönjohtajien näkemyksiä. Maaseudun uusi aika 18 (1), 5-16.

Tedre, Silva \& Pöllänen, Pirjo \& Voutilainen, Mari (toim.) (2016) Maaseudun näkökulmasta: tarkennuksia hyvinvointipalveluiden muutoksiin. Tampere: Juvenes Print.

Urry, John (1995) Consuming places. London and New York: Routledge.

Valkama, Pekka (toim.) (2013) Kylien organisoinnin hallinta. Tutkimus kyläyhteisöjen hallinnan järjestämistavoista ja -kokemuksista. Maaseutupolitiikan yhteistyöryhmän julkaisuja 6/2013. Maaseutupolitiikan yhteistyöryhmä.

Vartiainen, Pirkko \& Raisio, Harri (2011) Hallintotiede uuden ajan kynnyksellä - näkökulmana kompleksisuusajattelu. Teoksessa Turo Virtanen, Pertti Ahonen, Antti Syväjärvi, Pirkko Vartiainen, Juha Vartola \& Jari Vuori (toim.) Suomalainen hallinnon tutkimus. Mistä, mitä ja minne? Tampere: University Press, 388-412.

Yli-Viikari, Anja \& Lilja, Taina (2016) Se metsä on täynnä kyyneleitäni. Luonnon hyvinvointimerkityksiä jäljittämässä. Alue ja ympäristö 45 (1), 68-79.

WCED - World Commission on Environment and Development (1987) Our common future. Oxford: Oxford University Press. 